\title{
Ethiopia and Health Diplomacy during the COVID-19 Pandemic
}

\section{Ethiopia dan Diplomasi Kesehatan di Masa \\ Pandemi COVID-19}

\author{
Irfa Puspitasari \\ Universitas Airlangga
}

\begin{abstract}
ABSTRAK
Meskipun banyak pengamat studi Hubungan Internasional pesimis terhadap kerjasama antar negara, namun tulisan ini berupaya berargumentasi sebaliknya. Mewabahnya Covid-19 di awal tahun 2020 mengubah dinamika hubungan internasional. Respon negara yang sigap dan tepat, dapat meminimalkan kerugian akibat minimnya sumber daya dan kondisi krisis kesehatan maupun ekonomi sosial. Keberhasilan negara dalam merespon secara sigap semakin meningkat keberhasilannya dengan diplomasi kesehatan yang dilakukan oleh negara tersebut sehingga mendapatkan dukungan internasional dari pemerintah negara lain, dari kawasan maupun dari lembaga internasional. Tulisan ini berupaya membuktikan hal tersebut melalui pengalaman yang terjadi di Ethiopia.
\end{abstract}

Kata-kata kunci: Covid-19, diplomasi kesehatan, Ethiopia, dukungan internasional

Many scholars of International Relations studies are pessimistic about cooperation between countries, however this paper attempts to argue the opposite. Covid-19 outbreak in early 2020 changed the dynamics of international relations. An alert and appropriate response from the state can minimize losses despite lack of resources amid health and social economic crises. The country's success in responding swiftly has increased with health diplomacy carried out by the country so that it has received international support from other governments, regional as well as from international institutions. This paper seeks to prove this through Ethiopia's experiences.

Keywords: Covid-19, health diplomacy, Ethiopia, international support 
Sudah banyak peneliti Hubungan Internasional yang memprediksi menguatnya perspektif realis isolasionis di dunia pasca Covid-19. Mungkin benar, bahwa setelah kejadian Brexit, Uni Eropa menjadi terpecah. Apalagi sudah muncul kekhawatiran dengan adanya perang dagang antara Amerika Serikat dengan Cina pada tahun 2019, termasuk juga ketegangan antara Amerika Serikat dengan Korea Utara. Selain itu, terdapat gesekan-gesekan yang mengarah ke penempatan pasukan Tiongkok dan India di perbatasan di tahun 2020 dan perang proxy di Suriah antara Amerika Serikat dan Rusia. Berbagai peristiwa tersebut mengubah perimbangan kekuasaan politik keamanan internasional. Kondisi pandemi Covid-19 ini mengingatkan kita akan sejarah menjelang Perang Dunia I dan II. Pada saat itu pandemi yang dikenal dengan Flu Spanyol menyebabkan Perang Dunia I sempat terhenti karena memaksa negara-negara untuk sepakat berdamai dan membentuk Liga Bangsa-Bangsa. Namun, sayangnya perdamaian yang tergesagesa tersebut tidak bertahan lama, karena akhirnya pecahlah Perang Dunia II. Kondisi-kondisi tersebut serta penutupan perbatasan dan pembatasan sosial selama menghadapi pandemi Covid-19, mengakibatkan meningkatnya ketidakpercayaan antar berbagai identitas dari berbagai tingkat dan dimensi. Situasi ini menyebabkan banyak pakar memprediksi munculnya kecenderungan unilateralisme dan isolasionisme dalam interaksi antar bangsa.

\section{Peluang di Tengah Pandemi Covid-19: Diplomasi Kesehatan}

Tulisan ini berargumen, di tengah situasi yang tidak pasti ini masih ada peluang untuk kerjasama intra kawasan, antar kawasan maupun kerjasama yang menjembatani dimensi global dengan regional di berbagai kawasan yang lain misalnya Asia Tenggara, Amerika Latin, dan Afrika. Di Asia Tenggara misalnya, sudah ada kerjasama antar jaringan peneliti untuk menangani Covid-19 melalui ASEAN. Kerjasama ini muncul dengan mengingat pengalaman bersama ketika negara-negara di ASEAN menghadapi wabah SARS pada tahun 2002. Saat itu negaranegara di Asia Tenggara berjuang dalam dimensi hak intelektual atas sampel virus dan juga vaksinnya dalam berinteraksi dengan 
badan kesehatan dunia WHO dan afiliasinya dengan perusahaanperusahaan kesehatan multinasional raksasa dunia. Di saat yang bersamaan, di kawasan Amerika Latin, diplomasi kesehatan sudah mulai terdengar melalui Unasur. Maria Belen Herrero dan Diana Tussie (2015) menyebutnya sebagai revolusi sunyi dalam diplomasi kesehatan. Diplomasi kesehatan oleh negara-negara anggota suatu organisasi regional dapat memperkuat integrasi regional yang bersifat sosial dan post-hegemonis di area selain perdagangan. Diplomasi tersebut berada di area yang mampu memperkuat kerjasama fungsional dan koordinasi kelembagaan sehingga negara yang tergabung dapat memenuhi kebutuhan dasar warga negaranya. Selanjutnya dinamika tersebut mendorong transformasi dalam tingkat negara, kawasan maupun global karena berbagai interaksi antar aktor.

Krisis Covid-19 ini mengingatkan pentingnya diplomasi kesehatan dalam kebijakan luar negeri, karena memiliki potensi besar dalam meredam kepanikan. Pemerintah dari berbagai negara telah menyadari pentingnya diplomasi kesehatan, misalnya dengan deklarasi bersama Oslo 2007 antara perdana menteri dari Indonesia, Thailand, Afrika Selatan, Brazil, Senegal, Prancis, dan Norwegia. Kebijakan luar negeri yang impulsif seperti larangan bepergian, dan penghentian aktivitas ekonomi tidak memiliki landasan keilmuan, dan justru merugikan dalam jangka panjang. Perlunya diplomasi persuasif sehingga muncul kepercayaan, dan kerjasama dalam diseminasi data dan fakta keilmuan yang gratis serta sistem manajemen informasi real time terbukti lebih efektif dalam menghadapi masalah bersama. Negara asal wabah sebaiknya tidak distigmatisasi sehingga merasa percaya diri untuk lebih transparan dalam sharing informasi. Negara yang mampu memiliki tanggung jawab moral untuk mendukung mekanisme yang membantu negara lain mengatasi ancaman kesehatan (The Reporter 2020).

Belajar dari pengalaman di kawasan lain di Asia Tenggara dan Amerika Latin dalam berbagai tingkat regionalisme melalui diplomasi kesehatan, hal yang sama juga muncul di Afrika dengan bentuknya yang unik. Transformasi regionalisme karena diplomasi kesehatan yang juga muncul di Afrika tersebut, turut memperkuat kemampuan Ethiopia dalam menghadapi epidemi Covid-19. 
Tulisan ini terdiri dari empat bagian. Bagian pertama berisi identifikasi respon awal Ethiopia dalam menghadapi COVID-19; bagian kedua berisi identifikasi langkah-langkah strategis yang diambil oleh pemerintah Ethiopia; pada bagian ketiga berisi tentang analisis respons Ethiopia dengan melihat kesamaan maupun perbedaannya dengan langkah yang umum dilakukan oleh negara di dunia berikut permasalahan-permasalahan yang dihadapi; bagian keempat menyediakan analisis tingkat keberhasilan/kurang/tidak berhasil dan kontributif faktornya.

\section{Respon Awal Ethiopia terhadap Covid-19}

Kasus positif pertama di Ethiopia muncul mulai bulan 13 Maret 2020 (Xinhuanet 2020). Meskipun kasus positif belum muncul, akan tetapi pemerintah sejak awal telah menerapkan langkahlangkah kewaspadaan sejak bulan Januari 2020. Para petugas di bandara internasional Addis Ababa menerapkan screening secara ketat terhadap para penumpang yang datang. Kementerian kesehatan bekerja sama dengan pemerintah daerah juga melakukan screening dari rumah ke rumah, dan tes diagnosa. Para petugas yang berwenang menerapkan jejak rekam penularan, isolasi, karantina wajib, dan pengobatan (World Economic Forum 2020).

Pada intinya, secara domestik, pemerintah Ethiopia menerapkan empat langkah strategi penanganan darurat epidemi. Pertama, menerapkan upaya-upaya pencegahan saat berita wabah di Wuhan mulai tersebar secara internasional pada awal tahun. Kedua, meningkatkan upaya-upaya pencegahan secara lebih luas pada pertengahan Maret ketika kasus positif pertama mulai muncul. Pemerintah menutup akses daratnya, menutup sekolah, membebaskan tahanan untuk mengurangi kepadatan penjara, melakukan penyemprotan disinfektan di berbagai fasilitas publik dan mencegah kerumunan (The Jakarta Post 2020). Meskipun berat, akan tetapi pemerintah mengusahakan meningkatkan jumlah rapid test hingga 5 ribu tes per hari sampai pada bulan Mei. Pemerintah dari tiap lini berupaya meningkatkan kesadaran dan kewaspadaan masyarakat melalui pengumuman tiap hari. BUMN Telekomunikasi Ethiopia menggunakan ringtones untuk 
mengingatkan masyarakat akan pentingnya standar kesehatan seperti cuci tangan, pembatasan sosial, dan penggunaan masker. Aba Tilahun Woldemichael menjadi salah satu contoh kisah sukses sigapnya penanganan Covid di Ethiopia. Kakek yang oleh tim medis diestimasikan berusia setidaknya 109 tahun itu pulih dari Covid-19 setelah sebelumnya mengalami karantina selama 14 hari di rumah sakit Yeka Kotebe. Aba menjalani karantina setelah ketahuan positif saat menjalani rapid test meskipun saat itu yang bersangkutan belum menunjukkan gejala. Empat hari setelah tes, kondisi yang bersangkutan memburuk dan sempat bernafas dari selang oksigen (BBC 2020).

Ketiga, menerapkan protokol darurat bencana. Pada hari Rabu tanggal 8 April 2020, Perdana Menteri Abiy Ahmed mengumumkan kondisi darurat berdasar pasal 93 UUD. Darurat bencana tersebut berlaku selama lima bulan. Pihak yang melanggar protokol darurat tersebut mendapat ancaman sanksi hingga tiga tahun penjara (The Jakarta Post 2020). Pada bulan Maret, Komisi Pemilihan Umum (KPU) menunda pemilu yang dijadwalkan bulan Agustus hingga waktu yang tidak ditentukan. Tiga bulan kemudian, senat menetapkan PM Abiy Ahmed dapat terus memerintah hingga melampaui periodenya yaitu melewati bulan Oktober (Ipotnews 2020). Pemerintah mengubah fungsi asrama Universitas menjadi tempat karantina sehingga menambah kapasitas sekitar 15 ribu tempat tidur sehingga kapasitas total menjadi 75 ribu tempat tidur yang berfungsi sebagai tempat karantina. Pemerintah juga menyiapkan tempat pengobatan dengan kapasitas 5 ribu tempat tidur. Para tenaga medis yang menangani pasien Covid-19 juga mendapatkan perlindungan asuransi jiwa (World Economic Forum 2020). Bersamaan dengan kondisi darurat tersebut, Perdana Menteri menyiapkan dana darurat USD 1,64 milyar untuk distribusi makanan, kesehatan bila skenario terburuk terjadi, tempat penampungan sementara, dan keperluan terkait lainnya untuk masyarakat yang rentan termasuk untuk pengungsi. Dana ini banyak disalurkan lewat Woreda (semacam kabupaten) dan sejumlah kota (UNDCF 2020).

Upaya pemerintah dalam mengatasi pandemi bukannya tanpa hambatan. Dari dalam negeri, oposisi mengkritisi langkah yang dilakukan pemerintah misalnya penundaan pemilu dan keputusan 
senat untuk memberikan kesempatan bagi Abiy memerintah lebih panjang dibanding periode sesuai konstitusi. Oposisi juga menuding Abiy menggunakan kesempatan Covid ini untuk terus mempertahankan status quo, apalagi dengan menerapkan status darurat. Bekasketegangan komunal atau gerakan etnonasionalisme Oromo yang sempat muncul di permukaan tahun 2019 masih menyisakan permasalahan di tahun 2020 (Ipotnews 2020).

\section{Langkah-Langkah Strategis Pemerintah Ethiopia}

Pada gambar berikut, dapat dilihat lini masa respon cepat pemerintah Ethiopia dalam menghadapi Covid-19. Begitu kasus pertama terdeteksi pada pertengahan Maret, pemerintah segera menutup sekolah kecuali pada tingkat tertentu, membatalkan acara publik, membatasi acara publik yang berdampak pada kerumunan massa, melakukan kampanye publik yang terkoordinasi, dan mengontrol perjalanan internasional melalui screening. Bandara internasional di Addis Ababa merupakan bandara yang paling besar di Afrika. Selang beberapa hari, langkah tersebut juga segera diikuti dengan karantina dari kedatangan internasional dari negara yang berisiko tinggi. Pemerintah menutup sebagian kantor pemerintah, dan menutup semua sekolah dari berbagai tingkat. Akhir Maret, pemerintah menghentikan beberapa transportasi publik. Awal April, pemerintah menerapkan kondisi darurat negara, menyarankan warga untuk tetap di rumah, menyarankan warga menghindari transportasi publik, membatasi kerumunan lebih dari 10 orang. 
Gambar 1

Lini masa Covid-19 di Ethiopia

\section{Timeline for COVID-19 in Ethiopia}

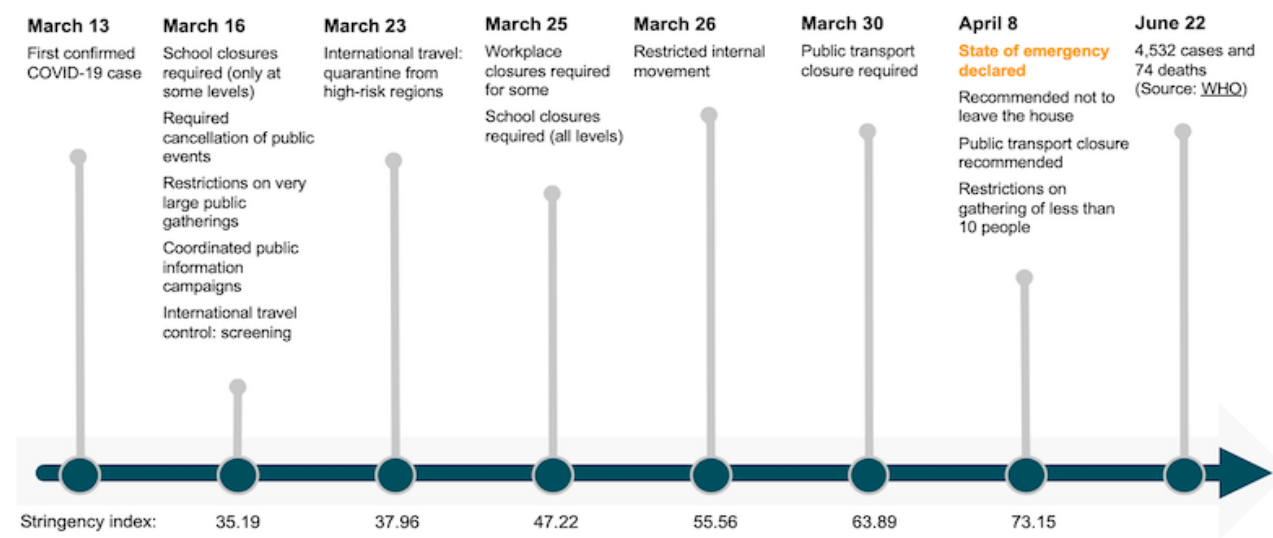

Sumber: Centre for Global Development (2020)

Keempat, tetap mendorong aktivitas produksi dan ekonomi lainnya untuk terus berlangsung selama krisis, sehingga meringankan tekanan ekonomi bagi kelompok sosial yang rentan terutama dari sektor informal. Pemerintah memberikan paket kesejahteraan ekonomi dengan prinsip bagi biaya dan risiko misalnya melalui protokol tripartit antara pemerintah, konfederasi bisnis, organisasi buruh, untuk mencegah PHK selama krisis berlangsung (World Economic Forum 2020). Untuk meningkatkan jaminan kesejahteraan pekerja, pemerintah menghapus pajak pendapatan selama empat bulan bagi perusahaan yang tetap menggaji karyawannya meskipun tidak bisa beroperasi (KPMG 2020). Kebijakan dalam hal keringanan pajak terlihat misalnya pada bulan April dewan menteri menyepakati untuk mengampuni pajak hutang sebelum 2014/2015, amnesti pajak bunga dan pajak hutang tahun 2015 hingga 2019 (KPMG 2020). Pemerintah memberikan subsidi dengan membebaskan biaya angkut barang kereta api dan meringankan biaya logistik bagi para eksportir (World Economic Forum, 2020). Upaya-upaya tersebut dilakukan sebagai respon kondisi perdagangan internasional yang cukup sulit ketika sebagian besar negara menutup perbatasan. Permintaan kopi, oil 
seed, menurun drastis. Bank pusat menyediakan dana tambahan sebesar USD 450 juta untuk bank swasta untuk memfasilitasi restrukturisasi kredit sehingga bisa mencegah kebangkrutan (UNCDF 2020).

Dalam ranah kebijakan luar negeri, Ethiopia sadar betapa pentingnya diplomasi kesehatan dalam menghadapi Covid. Sebagai negara partner Tiongkok, dua negara ini lewat Menteri Luar Negeri Ethiopia Gedu Andargachew dan Menteri Luar Negeri Tiongkok Wang Yi melakukan sambungan telepon. Hot Line diplomacy tersebut bagi Beijing menjadi upaya untuk menghangatkan hubungan government to government setelah ada insiden Guang Zhou yang berdampak pada reaksi negatif dari masyarakat Afrika. Ethiopia pun mendapatkan dukungan politik dari Tiongkok bagi Direktur Jenderal WHO Dr. Tedros Adhanom Ghebreyesus yang berasal dari Ethiopia setelah yang bersangkutan mendapat kritikan keras dari Washington (The Africa Report 2020). Tiongkok memiliki kepentingan jangka panjang dalam hal sumber daya mineral dan gas. Ethiopia mendapatkan salah satunya, fasilitas kesehatan penting seperti ekspansi Rumah Sakit Tirunesh Beijing (The Diplomat 2020). Pada bulan April, Tiongkok mengirim tim medis yang terdiri dari 12 pakar dengan pengalaman epidemi dari Rumah Sakit Universitas Sichuan, Pusat Pencegahan dan Pengawasan Penyakit Provinsi Sichuan, Rumah Sakit Rakyan Provinsi Sichuan, Rumah Sakit yang berafiliasi dengan Universitas Medis Barat Daya, dan Rumah Sakit yang berafiliasi dengan Universitas Chengdu dengan kepakaran Obat Tradisional Cina. Pakar tersebut berbagi pengalaman dengan lembaga kesehatan seperti Africa CDC, Menteri Kesehatan Ethiopia, dan Institut Kesehatan Masyarakat Ethiopia. Salah seorang tim bernama Zeng memperhatikan bahwa pemerintah Ethiopia mengerti bahayanya virus dan telah menerapkan standar kesehatan WHO. Zeng menambahkan, langkah yang telah dilakukan di Ethiopia melebihi ekspektasinya, meskipun Ethiopia minim sumber daya dan masih memiliki beberapa kekurangan (Global Times 2020).

Permasalahan internasional lain muncul ketika Saudi Arabia dan kemudian diikuti negara-negara lain mendeportasi migran dari Ethiopia, sehingga menuntut pemerintah Ethiopia untuk merapatkan barisan termasuk menerapkan diplomasi kesehatan 
yang tepat. Pasukan Houthi di Yaman pun turut mengusir para migran tersebut (The Jakarta Post 2020). Kondisi migran Ethiopia menjadi lebih rentan karena situasi perang di Yaman masih berlangsung setelah Saudi Arabia menginvasi negaranya tersebut (UN News 2020). Permasalahan pengusiran migran tersebut menunjukkan betapa rentannya para migran baik dalam kondisi normal maupun krisis. Antara 1 April hingga beberapa bulan berikutnya, Ethiopia menerima puluhan ribu kepulangan migran dari Somalia, Djibouti, Sudan, Saudi Arabia, Kuwait, Kenya, Lebanon dan lainnya (OCHA Services Relieve Web 2020; Financial Times 2020). Negara tetangganya khawatir keberadaan para migran ini dapat meningkatkan risiko penularan Covid-19 sehingga memulangkan mereka. Saat mereka sampai di tempat transit di Yaman, pasukan Houthi mengusir mereka karena ketakutan yang sama. Karantina di negara-negara tersebut kurang terjamin kebersihannya dan padat sehingga rawan penularan. Pemulangan migran dari Saudi Arabia, misalnya, dilakukan melalui pesawat untuk mengangkut ternak. Sesampainya di Addis Ababa, para migran tersebut tinggal sementara di tempat karantina seperti kampus dan gedung sekolah (Financial Times 2020). Dengan kondisi tersebut, setidaknya sebanyak 927 migran positif Covid sepulangnya ke Ethiopia.

\section{Diplomasi Kesehatan: Upaya Pemerintah dalam Menghadapi Repatriasi Besar-Besaran}

Ethiopia mengupayakan diplomasi kesehatan kepada negaranegara tetangganya supaya jalannya proses repatriasi tidak membuat Ethiopia kewalahan. Kepala Delegasi Ethiopia untuk International Organization for Migration (IOM) menyatakan bahwa dalam pengelolaan repatriasi di tengah Covid, perlu ada diskusi antar pemerintah untuk mencapai kesepakatan mengenai pendekatan bersama dalam mengatasi Covid (The New York Times 2020). Badan dunia menunjuk International Organization for Migration untuk bekerja sama dengan pemerintah Ethiopia dalam memfasilitasi tempat karantina di Addis Ababa dan kawasan sekitar (OCHA Services reliefweb 2020). Staf PBB juga turut membantu diplomasi Ethiopia supaya Saudi Arabia dan negaranegara tetangganya bersedia melaksanakan proses deportasi yang 
humanis.

Kolaborasi fungsional tersebut dilakukan lewat jaringan pantau laboratorium di kawasan yang terintegrasi bernama Africa CDC Regional Integrated Surveillance Laboratory Network (RISLNET) di Zambia, Kenya, Gabon, Nigeria dan Senegal. Kolaborasi tersebut berfungsi untuk perencanaan, siap siaga pandemi, dan kesigapan penanggulangannya. Kolaborasi fungsional dengan tingkat global dilakukan lewat jaringan bernama Africa CDC Anti-Microbial Resistance and Surveillance Network (Africa CDC AMRSNET) yang terhubung dengan program GLASS WHO. Kolaborasi tersebut berfungsi diantaranya untuk mendapatkan data informasi yang berkualitas dan pemberian bantuan teknis (Amukele 2017). Secara sederhana, Ethiopia dan negara-negara tetangganya memiliki respon yang kolaboratif dan dapat memberikan layanan kesehatan kepada masyarakatnya sementara WHO mendapatkan informasi. Akankah data informasi tersebut dibawa oleh WTO kepada perusahaan farmasi multinasional raksasa? Akankah pertukaran tersebut adil? Pertanyaan-pertanyaan tersebut dapat menjadi rumusan permasalahan penelitian selanjutnya. Pada bulan Juni, anggota Afrika CDC sepakat mengembangkan kerjasama untuk mempercepat test, pelacakan dan perawatan pasien Covid-19 (Africa CDC 2020).

Pemerintah Ethiopia menerapkan standar yang berbeda dibanding negara tetangganya seperti Rwanda, Uganda dan Mauritius yang lebih memilih menerapkan lockdown. (The Jakarta Post, 2020). Ethiopia berhasil menekan kasus positif di negaranya dilihat dari kecilnya rasio kematian. Tercatat hingga akhir Juni 2020, sebanyak 103 pasien Covid-19 meninggal dari 5846 yang positif (OCHA Services reliefweb 2020). Hal tersebut berarti rasio kematian cukup rendah yaitu 1,7 persen dibanding dengan rasio kematian secara global yaitu 4,9 persen (WHO 2020). Negara ini berhasil mengatasi minimnya sumber daya dalam mengatasi krisis dengan respon yang sigap, diplomasi kesehatan dan dukungan internasional. 


\section{Simpulan}

Meskipun kerjasama kawasan dalam mengatasi Covid terdengar kurang, bukan berarti tidak ada. Masih ada upaya bersama di kawasan Afrika, misalnya oleh integrasi regional Uni Afrika melalui lembaganya, Africa Centre for Disease Control and Prevention (Africa CDC). Kolaborasi kawasan ini bekerjasama dengan World Health Organization. Tidak semua negara puas dengan kolaborasi kawasan tersebut. Tanzania kerap memberikan kritikan terhadap upaya penanganan Africa CDC. Kerjasama antar kawasan pun masih terlihat, diantaranya dengan bantuan peralatan tes dari Jerman yang disalurkan lewat Africa CDC yang juga diperuntukkan bagi Ethiopia sebagai salah satu anggota aktifnya (Africa CDC 2020). Africa CDC terbentuk tahun 2017 sebagai bagian dari integrasi kawasan Uni Afrika. Markas besarnya berada di Addis Ababa.

Sebagaimana yang terjadi di kawasan Amerika Latin, koordinasi dan kerjasama fungsional di area kesehatan pun muncul di Afrika. Terdapat transformasi pola interaksi antara lembaga regional dengan global pada saat Covid-19 ini dibanding dengan saat dunia menghadapi SARS pada dekade sebelumnya. Jika pada saat SARS badan-badan maupun aktor regional cenderung kritis terhadap kebijakan WHO, maka untuk saat ini dimensi kolaborasi cenderung lebih terasa dibanding dimensi konfliknya. Di Amerika Latin, diplomasi kesehatan Brasil di BRICS dan cabang WHO PAHO di kawasan menggeser fungsi UNASUR sebagai wadah kolaborasi. Terasa pengaruh negara donor misal Inggris dan Jerman serta WHO dalam kolaborasi fungsional Africa CDC.

\section{Referensi}

\section{Artikel Daring}

Africa CDC, 2020. "African Union rolls out Partnership to Accelerate COVID-19 Testing", Africa CDC, 4 Juni 2020, [daring] dalam https://africacdc.org/news-item/africanunion-rolls-out-partnership-to-accelerate-covid-19-testing/ [diakses pada 12 September 2020]. 
Amukele, Timothy. 2017. Africa CDC: Establishing Integrated Surveillance and Laboratory Networks for Rapid Disease Detection and Response, Control, Prevention, and Clinical Care in Africa. African Journal of Laboratory Medicine. 6. 10.4102/ ajlm.v6i1.638. [daring] dalam https://www.researchgate. net/publication/317818916 Africa_CDC Establishing Integrated Surveillance and Laboratory Networks for Rapid Disease Detection and Response Control Prevention and Clinical Care in Africa [diakses pada 6 September 2020].

BBC, 2020. "Coronavirus in Ethiopia: 'Incredible recovery of man aged over 100”, BBC, 26 Juni 2020, [daring] dalam https:// www.bbc.com/news/world-africa-53191633 [diakses pada 5 September 2020].

Centre for Global Development, 2020. "Estimating the Indirect Health Impacts of COVID-19 in Ethiopia", Centre for Global Development, 24 Juni 2020, [daring] dalam https://www. cgdev.org/blog/estimating-indirect-health-impacts-covid-19ethiopia [diakses pada 12 September 2020].

Global Times, 2020. "Chinese medical team aims to stifle epidemic in Ethiopia, prevent major outbreak", Global Times, 29 April 2020, [daring] dalam https://www.globaltimes.cn/ content/1187095.shtml [diakses pada 13 September 2020].

Herrero, Maria. B., \& Diana Tussie. 2015. UNASUR Health: A quiet revolution in health diplomacy in South America. Global social policy, 15(3), 261-277. https://doi. org/10.1177/1468018115599818. [daring] dalam https://www. ncbi.nlm.nih.gov/pmc/articles/PMC4639827/ [diakses pada 6 September 2020].

Ipotnews, 2020. “Ethiopia under Abiy Ahmed”. Indopremier, 4 Juli 2020,[daring]dalamhttps://www.indopremier.com/ipotnews/ newsDetail.php?jdl=Ethiopia under Abiy Ahmed\&news id $=1483249 \&$ group_news = ALLNEWS\&taging s u b ty pe =ER I T R E A \& n a m e $=\& \mathrm{~s}$ e a r c h $=y$ general\&q=ERITREA,\%20\&halaman $=1$ [diakses pada 12 September 2020]. 
KPMG, 2020. "Ethiopia: Government and institution measures in response to COVID-19", KPMG, 24 Juni 2020, [daring] dalam https://home.kpmg/xx/en/home/insights/2020/04/ethiopiagovernment-and-institution-measures-in-response-to-covid. html [diakses pada 27 Agustus 2020]

OCHA Services Reliefweb, 2020. "Ethiopia: COVID-19 Response Overview", OCHA Services Reliefwab, 2020, [daring] dalam https://reliefweb.int/report/ethiopia/ethiopia-covid-19situation-report-no-13-16-30-june-2020 [diakses pada 10 September 2020]

The Africa Report, 2020. "Coronavirus: African COVID-19 aid reemerges as Chinese priority”, The Africa Report, 19 Mei 2020, [daring] dalam https://www.theafricareport.com/28265/ coronavirus-african-covid-19-aid-re-emerges-as-chinesepriority/ [diakses pada 13 September 2020].

The Diplomat, 2020. “Taiwan's Health Diplomacy Didn't Start With the COVID-19 Crisis", The Diplomat, 16 April 2020, [daring] dalam https://thediplomat.com/2020/04/taiwans-healthdiplomacy-didnt-start-with-the-covid-19-crisis/ [diakses pada 13 September 2020].

The Jakarta Post, 2020. "Ethiopia declares state of emergency to fight coronavirus", The Jakarta Post, 9 April 2020, [daring] dalam https://www.thejakartapost.com/news/2020/04/08/ ethiopia-declares-state-of-emergency-to-fight-coronavirus. html [diakses pada 26 Agustus 2020]

The New York Times, 2020. "Ethiopian Workers Are Forced to Return Home, Some With Coronavirus", The New York Times, 1 Agustus 2020, [daring] dalam https://www.nytimes. com/2020/08/01/world/africa/ethiopian-migrant-workerscoronavirus.html [diakses pada 10 September 2020].

The Reporter, 2020. "The case for global health diplomacy", The Reporter, 22 Februari 2020, [daring] dalam https://www. thereporterethiopia.com/article/case-global-health-diplomacy [diakses pada 13 September 2020].

UN News, 2020. "In Yemen, thousands of Ethiopian migrants 
Ethiopia and Health Diplomacy during the Covid-19 Pandemic

stranded, COVID-19 likely widespread", UN News, 14 Juli 2020, [daring] dalam https://news.un.org/en/ story/2020/07/1068301 [diakses pada 12 September 2020].

UNCDF, 2020. "Ethiopian Government on the Forefront of COVID-19", UNCDF, 16 April 2020, [daring] dalam https:// www.uncdf.org/article/5528/ethiopian-government-on-theforefront-of-covid-19 [diakses pada 12 September 2020].

World Economic Forum, 2020. "Ethiopia's unconventional COVID-19 response", World Economic Forum, 5 Juni, [daring] dalam https://www.weforum.org/agenda/2020/06/ethiopiacovid19-response/ [diakses pada 25 Agustus 2020]

World Health Organization, 2020. "Coronavirus disease (COVID-19) Situation Report-162", World Health Organization, 30 Juni 2020 [daring] dalam https://www. who.int/docs/default-source/coronaviruse/20200630covid-19-sitrep-162.pdf?sfvrsn=eo0a5466 2 [diakses pada 11 September 2020] 